\begin{tabular}{|l|l|l|}
\hline \multicolumn{2}{|c|}{ PublisherInfo } \\
\hline \hline PublisherName & $:$ & BioMed Central \\
\hline \hline PublisherLocation & $:$ & London \\
\hline \hline PublisherImprintName & $:$ & BioMed Central \\
\hline \hline
\end{tabular}

Irish science funds on 'pause'

\begin{tabular}{|l|l|l||}
\hline \multicolumn{2}{|c|}{ ArticleInfo } \\
\hline \hline ArticleID & $:$ & 4869 \\
\hline \hline ArticleDOI & $:$ & $10.1186 /$ gb-spotlight-20031031-01 \\
\hline \hline ArticleCitationID & $:$ & spotlight-20031031-01 \\
\hline \hline ArticleSequenceNumber & $:$ & 221 \\
\hline \hline ArticleCategory & $:$ & Research news \\
\hline ArticleFirstPage & $:$ & 1 \\
\hline \hline ArticleLastPage & $:$ & 3 \\
\hline \hline & $:$ & RegistrationDate : 2003-10-31 \\
ArticleHistory & $:$ & OnlineDate \\
\hline \hline ArticleCopyright & $:$ & BioMed Central Ltd2003-10-31 \\
\hline \hline ArticleGrants & $:$ & \\
\hline \hline ArticleContext & $:$ & 130594411 \\
\hline \hline
\end{tabular}




\section{Amanda Haverty}

Email: Amandahaverty@eircom.net

As Ireland's "Celtic Tiger" economy whimpered its last, funding to the country's "Programme for Research in Third Level Institutions" (PRTLI) was "paused" by the government last November, a move strongly criticized by academics and researchers.

However, nearly a year later, the Higher Education Authority, which administers the government's flagship research program has told us that the pause may soon be lifted.

"Discussions are taking place at the highest level of government on the matter, and it is hoped that the issue of the pause will be resolved within the next month when the estimates for 2004 [outline of public expenditure for 2004] will be published," a spokesman said.

The PRTLI was set up under the government's National Development Plan in 2001 with assistance from the European Regional Development Fund. It promised investment of over $€ 140$ million in research until at least 2006.

Since the halt in funds was announced, the Irish Research Scientists' Association (IRSA) has been lobbying the Department of Education and Science to fully reinstate the program.

Chair-elect of the IRSA John Donovan from the Dublin Institute of Technology told us that he was cynical about promises to reinstate the fund and that the pause historically "is the same as a cut or an abandonment."

Donovan said that the infrastructure of research in Ireland and future confidence in Irish research science was being undermined by the stop-start nature of funding.

He said scientists are affected directly through the loss of the scheme and the infrastructure it is supposed to be developing, but also indirectly "in that the trust and confidence of researchers in the funding system is severely undermined."

He is not the only senior scientist to come forward over the damage afflicted by the PRTLI pause. Earlier this month, the Minister for Education and Science Noel Dempsey told the country's parliament that he hoped the crisis could be resolved, but gave no timescale for the PRTLI program to be fully reinstated.

He added that if Ireland was to position itself as a knowledge economy, it needed the social and economic growth that will flow from continuing investment in research and knowledge. However, he also offered no timescale for when this investment could proceed.

The move resulted in the president of the National University of Ireland (NUI), Galway, Iognaid O'Muircheartaigh, publicly warning the government to honor its commitment to Third Level Education if a crisis in Ireland's research institutions is to be avoided.

Ger Hurley, dean of research at NUI Galway, told us that the importance of reinstating the PRTLI capital funding "cannot be understated." 
He said the increased investment advocated under the National Development Plan "moved us up the value chain," but he added, "Pausing the program has caused huge difficulties, not least the damage to our reputation, which was built up over many years, but tarnished overnight."

"It is not too late to mitigate this damage. Above all, the continuity of research must be maintained. A start-stop approach doesn't work and will remove Ireland from the league of countries with advanced research capability," he said.

\section{References}

1. Higher Education Authority, [http://www.hea.ie/]

2. European Regional Development Fund, [http://europa.eu.int/scadplus/leg/en/lvb/160015.htm]

3. Irish Research Scientists' Association, [http://www.irsa.ie/]

4. Noel Dempsey, [http://www.fiannafail.ie/minister_cv_50.htm]

5. Iognaid O'Muircheartaigh, [http://www.nuigalway.ie/administration_services/presidents_office/ message.html] 